Article

\title{
Failure Modes, Effects and Criticality Analysis for Wind Turbines Considering Climatic Regions and Comparing Geared and Direct Drive Wind Turbines
}

\author{
Samet Ozturk ${ }^{1}$, Vasilis M. Fthenakis ${ }^{1,{ }^{*}}$, Stefan Faulstich ${ }^{2}$ \\ 1 Columbia University, 116th St \& Broadway, New York, NY 10027 \\ 2 Fraunhofer Institute for Energy Economics and Energy System Technology, Kassel, Germany \\ * Corresponding author:vmf5@columbia.edu
}

\begin{abstract}
The wind industry is looking for ways to accurately predict the reliability and availability of newly installed wind turbines. Failure modes, effects and criticality analysis (FMECA) is a technique utilized for determining the critical subsystems of wind turbines. There are several studies which applied FMECA for wind turbines in the literature, but no studies so far have considered different weather conditions or climatic regions. Furthermore, various design types of wind turbines have been analyzed applying FMECA but no study so far has applied FMECA to compare the reliability of geared and direct-drive wind turbines. We propose to fill these gaps by using Koppen-Geiger climatic regions and two different turbine models of direct-drive and geared-drive concepts. A case study is applied on German wind farms utilizing the WMEP database which contains wind turbine failure data from 1989 to 2008. This proposed methodology increases the accuracy of reliability and availability predictions and compares different wind turbine design types and eliminates underestimation of impacts of different weather conditions.
\end{abstract}

Keywords: Reliability; FMEA; wind turbines; climatic conditions; wind turbine type

\section{Introduction}

Wind energy is one of the most profitable among renewable and clean energy sources and its deployment is constantly increasing having doubled during the last six years [1]. However, large deployment of a variable energy creates some concerns regarding reliability and availability. Reliability is defined as the ability to perform as required, without failure, for a given time interval under given conditions, whereas availability is defined as the ability to be in a state to perform as required in the International Electrotechnical commission (IEC) 60050 standards [2, 3]. In order to improve the reliability and availability of wind turbines the first step is to determine the causes of failures, failure frequencies, effects of failures and criticalities accurately. The aim of this study is to generalize the findings on the reliability predictions so that they guide the deployment of new wind turbines.

Failure Modes and Effects Analysis (FMEA) is a method which detects potential failure modes of a product during its life cycle; the effects of these failures; and the criticality of these failure effects in product functionality [4]. It is widely utilized for mechanical, electrical, electronical and structural systems as well as chemical processes in the industry to sufficiently allocate budget for high priorities. Failure Modes, Effects and Criticality Analysis (FMECA) is an extension of FMEA by including criticality analysis which is used to quantify criticality of the failure modes in a specific subsystem or component. There are several studies which applied FMEA for wind turbines in the literature [5 - 10, 15 - 20]. 
Andrawus et al [5] conducted FMECA to optimize the maintenance strategy for 26x600 kW wind farm whereas qualitative FMEA is utilized to prioritize the failure modes in other studies using data from specific turbine models [6-8]. Dinmohammadi and Shafiee [9] used a fuzzy-FMEA and compared the results with traditional FMEA but they only used a single turbine model and did not consider climatic conditions. Shafiee and Dinmohammadi [10] compared onshore and offshore FMEA results using field data from several resources [11-14] whereas a combined field data is utilized in [15] to apply FMEA. Direct-drive wind turbine model is distinctively considered for FMEA in [16] whereas other studies either used combined field data or geared-drive wind turbine models for FMEA application. FMEA is applied for design improvement perspective in [17, 18] considering a specific turbine model while required maintenance action is added to FMEA in [19]. Tazi et al [20] proposed a hybrid cost-FMEA for wind turbine reliability analysis and used a combined field data from several sources [14, 21-24]. However, no studies have, so far, applied FMECA considering different weather conditions or climatic regions. Also, in several references FMEA is applied to different turbine configurations as considering geared or direct drive or combination of these turbine types but no study compared the FMEA results from direct drive and geared wind turbine technologies comparatively. Nevertheless, as it is stated in [20] the criticality outcomes are influenced by the weather impacts. Therefore, our study aims to fill these literature gaps in by achieving the following:

1- Determining impacts of climatic regions on wind turbine subsystem annual failure rate and downtime per failure values by using failure data from an identical turbine model.

2- Investigating wind turbine subsystem and component failure causes, effects and criticalities considering climatic regions.

3- Defining the differences in annual failure rate and downtime for direct drive and geared wind turbines and revealing differences in failure causes of such failures, effects and criticalities.

\section{Materials and Methods}

This study has four different methodological dimensions; these are a) obtaining reliability and availability metrics for an identical turbine model for different climatic regions, b) applying FMECA on the identical turbine models for different climatic regions, c) revealing reliability metrics for two different turbine types for same climatic region and d) applying FMECA on different turbine types. To reach the first objective, there is a need to classify wind turbine locations based on the meteorological parameters. To attain the second objective a FMECA is applied to all wind turbines considering a turbine model which is spread to different climatic regions. To reach the third objective, two turbine models which represent two different turbine designs are selected from WMEP database and FMECA is applied considering on them. 


\subsection{Climatic regions}

Koppen-Geiger is a climate classification and being cited by almost 5,000 studies in variety of disciplines [25]. Koppen-Geiger climatic regions which are determined based on annual precipitation and temperature records along with seasonal temperature records utilize 12,396 precipitation and 4,844 temperature data stations globally and apply several temperature and precipitation criteria [25]. In Germany, there are four Koppen-Geiger climatic regions as it is seen in Figure 1. Climatic regions which are present in Germany as follows:

- Cfa: Temperate-without dry season-hot summer

- Cfb: Temperate-without dry season-warm summer

- Dfb: Cold-without dry season-warm summer

- Dfc: Cold-without dry season-cold summer

Criteria for the classification of the climatic regions of interest are given in Table 1 [25].

Table 1. Criteria for the climatic region classifications for Germany

\begin{tabular}{|c|c|c|c|c|}
\hline 1st & 2nd & 3 rd & Description & Criteria* \\
\hline \multirow[t]{7}{*}{ C } & & & Temperate & $\mathrm{T}_{\text {hot }} \geq 10 \& 0<\mathrm{T}_{\text {cold }}<18$ \\
\hline & $\mathrm{s}$ & & - Dry Summer & $P_{\text {sdry }}<40 \& P_{\text {sdry }}<P_{\text {wwet }} / 3$ \\
\hline & $\mathrm{w}$ & & - Dry Winter & $P_{\text {wdry }}<P_{\text {swet }} / 10$ \\
\hline & $\mathrm{f}$ & & - Without dry season & Not $(\mathrm{Cs})$ or $(\mathrm{Cw})$ \\
\hline & & $\mathrm{a}$ & - Hot Summer & Thot $\geq 22$ \\
\hline & & $\mathrm{b}$ & - Warm Summer & Not (a) \& $\mathrm{T}_{\operatorname{mon} 10} \geq 4$ \\
\hline & & c & - Cold Summer & $\operatorname{Not}(\mathrm{a}$ or $\mathrm{b}) \& 1 \leq \mathrm{T}_{\operatorname{mon} 10}<4$ \\
\hline \multirow[t]{8}{*}{$\mathrm{D}$} & & & Cold & $\mathrm{T}_{\text {hot }} \geq 10 \& \mathrm{~T}_{\text {cold }} \leq 0$ \\
\hline & s & & - Dry Summer & $P_{\text {sdry }}<40 \& P_{\text {sdry }}<P_{\text {wwet }} / 3$ \\
\hline & $\mathrm{w}$ & & - Dry Winter & $P_{\text {wdry }}<P_{\text {swet }} / 10$ \\
\hline & $\mathrm{f}$ & & - Without dry season & Not $(\mathrm{Ds})$ or $(\mathrm{Dw})$ \\
\hline & & a & - Hot Summer & $T_{\text {hot }} \geq 22$ \\
\hline & & $\mathrm{b}$ & - Warm Summer & Not (a) \& $T_{m o n} 10 \geq 4$ \\
\hline & & c & - Cold Summer & $\operatorname{Not}(a, b$ or $d)$ \\
\hline & & $\mathrm{d}$ & - Very Cold Winter & Not $(\mathrm{a}$ or $\mathrm{b}) \& \mathrm{~T}_{\text {cold }}<-38$ \\
\hline
\end{tabular}

${ }^{*} \mathrm{~T}_{\text {hot }}=$ temperature of the hottest month, $\mathrm{T}_{\text {cold }}=$ temperature of the coldest month, $\mathrm{T}_{\text {mon10 }}=$ number of months where the temperature is above 10, $P_{\text {dry }}=$ precipitation of the driest month, $P_{\text {sdry }}=$ precipitation of the driest month in summer, $P_{w d r y}=$ precipitation of the driest month in winter, $P_{\text {swet }}=$ precipitation of the wettest month in summer, $P_{\text {wwet }}=$ precipitation of the wettest month in winter. 


\subsection{WMEP data}

The source of our failure data is the WMEP database which covers wind turbines operating in Germany between 1989 and 2008. The events in WMEP database include scheduled maintenance, scheduled maintenance with replacement or repair, and unscheduled maintenance with a replacement or repair with additional information such as energy delivery. The WMEP survey collected operations and maintenance data from more than 1500 wind turbines, in this study data from 575 of them are ready to be utilized with 6188 turbine years of operation and including 19,242 events considering a repair or replacement.

Figure 1 shows the wind turbine locations in Germany in the WMEP database that we use in this study. There are 427 wind turbines - 4526 turbine years in Cfb region, 122 wind turbines - 1346 turbine years in Dfb region, 25 wind turbines - 306 turbine years in Dfc region in the WMEP database.

For the investigation of the climatic region effect, a control wind turbine model is selected among the highest most common in the WMEP database. For the investigation of turbine type impact, two different wind turbine models are selected as the details are given in Table 2. A sensitivity analysis has been conducted to see the impacts of turbine capacity, rotor diameter and hub heights for wind turbine model reliability comparison.

Table 2. Selected wind turbines from WMEP database for this study

\begin{tabular}{|l|l|l|l|l|l|l|}
\hline & Direct-drive WTs & Geared-drive & \multicolumn{4}{|l|}{ Control group of WTs (geared-drive) } \\
\cline { 4 - 8 } & & WTs & All & Cfb & Dfb & Dfc \\
\hline Number of WTs & 48 & 15 & 39 & 15 & 18 & 6 \\
\hline Operation years & 493 turbine-years & 152 turbine-years & 432 & 152 & 208 & 73 \\
\hline Capacity & $500 \mathrm{~kW}$ & $500 \mathrm{~kW}$ & $500 \mathrm{~kW}$ & & \\
\hline Rotor Diameter & $40 \mathrm{~m}$ & $39 \mathrm{~m}$ & $39 \mathrm{~m}$ & \\
\hline
\end{tabular}




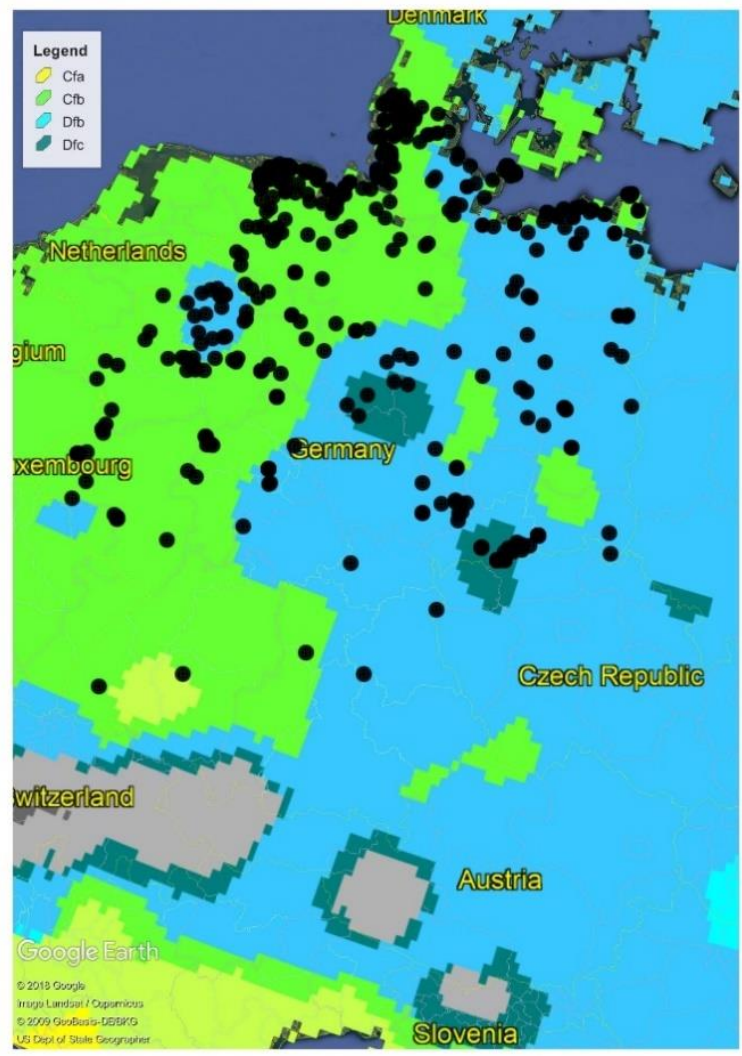

Fig. 1. Map of 575 wind turbines (black dots) in different climatic regions in Germany

\subsection{FMECA approach and components}

FMECA requires a taxonomy for wind turbine subsystems. In this study, subsystems and assemblies of wind turbines are adopted considering the classification in [15] and WMEP database classifications. Table 3 lists the subsystems and assemblies of a typical wind turbine.

Table 3. Subsystems and assemblies of wind turbines

\begin{tabular}{|l|l|}
\hline $\begin{array}{l}\text { Subsystems of wind } \\
\text { turbines }\end{array}$ & Components of wind turbines \\
\hline Hub & Hub body, pitch mechanism, pitch bearings \\
\hline Structure & Foundations, tower/tower bolts, nacelle frame, nacelle cover and ladder \\
\hline Rotor blades & Blade bolts, blade shell and aerodynamic brakes \\
\hline Mechanical brake & Brake disc, brake pads and brake shoe \\
\hline Drive train & Rotor bearings, drive shafts and couplings \\
\hline Gearbox & Bearings, wheels, gear shaft and sealings \\
\hline Generator & Generator windings, generator brushes and bearings \\
\hline Yaw system & Yaw bearings, yaw motor, wheels and pinions \\
\hline Sensors & $\begin{array}{l}\text { Anemometer/wind vane, vibration switch, temperature, oil pressure } \\
\text { switch, power sensor and revolution counter }\end{array}$ \\
\hline Hydraulic System & Hydraulic pump, pump motor, valves and hydraulic pipes/hoses \\
\hline
\end{tabular}




\begin{tabular}{|l|l|}
\hline Electrical System & Converter, fuses, switches and cables/connections \\
\hline Control System & Electronic control unit, relay, measurement cables and connections \\
\hline
\end{tabular}

FMECA consists of four main components such as failure modes, failure causes, effects of the failures and failure mode criticality numbers. Failure modes represent the type of failure occurring in every subsystem whereas failure mechanisms are the causes that lead to failures. Effects of the failures are simply consequences whereas failure mode criticality numbers are calculated as sum of expected cost from the failures and loss of energy production for every subsystem.

\subsubsection{Failure modes}

Failure modes can be classified as the failures which happen in the specific subsystem (i.e. blade failure, gearbox failure, generator failure, etc.) [18] or more specifically such as fatigue and fracture in toothed shaft of a gearbox, loss of function in lubricant system [26] depending on the data availability. Database which is used in this study does not include detail data about the failure modes beyond the subsystem where the failure occurs.

\subsubsection{Failure causes}

In this study, failure causes in WMEP database which are given in Table 4 are used. They are high wind, grid failure, lightning, icing, malfunction of control systems, component wear or failure, loosening of parts, other causes and unknown causes. Grid failures depend on the region in which wind turbine is operated, however it is not a climatic impact, so it is not an interest of investigation.

Table 4. Locations, causes and effects of the failure which are included in WMEP database

\begin{tabular}{|l|l|l|}
\hline Failure locations & Failure causes & Failure effects \\
\hline Structures failures & High wind & Overspeed \\
\hline Rotor blade failures & Grid failure & Overload \\
\hline Mechanical brake failures & Lightning & Noise \\
\hline Drive train failures & Icing & Vibration \\
\hline Gearbox failures & Malfunction of control system & Reduced power \\
\hline Generator failures & Component wear or failure & Causing follow-up damage \\
\hline Yaw system failures & Loosening of parts & Plant stoppage \\
\hline Sensor failures & Other causes & Other consequences \\
\hline Hydraulic System failures & Cause unknown & \\
\hline Electrical System failures & & \\
\hline Control System failures & & \\
\hline Hub failures & & \\
\hline
\end{tabular}

\subsubsection{Failure effects}


Failure effects can be classified in the same way with failure causes which are given in Table 4. Eight effects of failures are used for FMECA in this study. They are overspeed, overload, noise, vibration, reduced power, causing follow-up damage, plant stoppage and other consequences.

\subsubsection{Criticality of failure modes}

Criticality Priority Number (CPN) is the one of the most important outcomes of this FMECA application. It is estimated as in the following product:

\section{Criticality Priority Number $=$ Occurrence Severity $*$ Consequence Severity $*$$$
\text { Non - detection Severity }
$$

It is stated in the literature that $99 \%$ of the equipment failures give malfunctioning signals about the potentiality of the malfunction of the equipment [20]. Condition monitoring systems (CMS) enable the detection of the failures in wind turbine subsystems such as gearbox, drive train, generator and tower by use of vibration, heat and pressure sensors [27]. In wind turbines, however, failures often suddenly appear and can not be detected. Visual inspection in scheduled maintenances is also another way to detect potential anomalies in a wind turbine. WMEP database consists of information of scheduled maintenances which were applied regularly on the wind turbines but does not cover the detection rate for the failures. Therefore, it is assumed that visual inspection detects potential failures equally for every subsystem. Although this is a strong assumption, there is no other practical option for estimating detection rate other than assuming that it is equal for every subsystems for this study.

In this study, CPN is demonstrated by two different metrics such as Cost Criticality Number $(\mathrm{CCN})$ and Downtime Criticality Number (DCN). Although in most cases cost criticality is important for the wind operators, downtime criticality would be more important for some rare cases such as energy security for military or health operations. Furthermore, the behavior of CCN and DCN can be very different depending on the external and internal conditions of wind turbines and thus operators can arrange their actions based on their prioritization. CCN measures the risk of having failure in terms of cost in a subsystem of wind turbine while DCN represents the risk of having failure in terms of time. To estimate DCN downtime per failure is calculated by multiplying total downtime per failure and annual failure rate. Evaluation of cost criticality number requires two subcomponents which are cost for the failure mode and cost for loss of energy production for this study. Cost for the failure mode is evaluated by multiplication of annual failure rate and cost per failure whereas cost for loss of energy production is calculated by multiplying lost energy production and electricity price. The generic cost criticality number is estimated by Equation (2). Equations ( 3 and 4 ) are used to estimate the cost for the failure mode and loss of energy production, respectively [13]. Equation (5) evaluates lost energy production and equation (6) estimates the downtime criticality number. 


\section{Lost energy production $=$}

Capacity factor $*$ Wind turbine nominal power $*$ Downtime per failure $*$ Annual Failure Rate (5)

Downtime Criticality Number $=$ Downtime per failure $*$ Annual failure rate (6)

where $\mathrm{n}$ represents subsystems, $\mathrm{p}_{\mathrm{n}}$ is annual failure rate occurring and $\mathrm{c}_{\mathrm{n}}$ is cost per failure in subsystem " $n$ ". To estimate the lost energy production in Equation (5), the capacity factor is assumed to be $33 \%$ and average electricity selling tariff in the US is assumed to be 12 cents/kWh in Equation (4). It should be noted that this is a conservative assumption since most of the failures occur with the high wind rather than no wind conditions.

The FMECA methodology is applied as in the following:

1- Annual failure rates and downtime per failure values are determined.

2- Downtime and cost criticality values are computed for every subsystem for wind turbines.

3- The failures in wind turbines in different climatic regions are sorted.

4- Failure rates, downtime per failures, failure modes, and effects of different subsystems in different climatic regions are determined and their downtime and cost criticality values are computed.

5- The results are compared between climatic regions and targeted turbine population.

The comparison between geared and direct-drive wind turbines are applied on $500 \mathrm{~kW}$ geared and direct-drive wind turbines in the same climatic region $\mathrm{Cfb}$.

A short example on $\mathrm{CCN}$ and $\mathrm{DCN}$ computations for rotor blades for climatic region $\mathrm{Cfb}$ are demonstrated in Table 5.

Table 5. An example of calculation of CCN and DCN

\begin{tabular}{|c|c|c|c|c|c|c|}
\hline & $\begin{array}{c}\text { Replacement } \\
\text { cost \$ [25, 26] }\end{array}$ & AFR & $\begin{array}{c}\text { Downtime } \\
\text { per failure }\end{array}$ & $\begin{array}{c}\text { Cost of lost energy } \\
\text { production }\end{array}$ & CCN (\$) & DCN (hr) \\
\hline $\begin{array}{c}\text { Rotor } \\
\text { blades }\end{array}$ & 47,584 & 0.26 & 22 & $0.33^{*} 500^{*} 22^{*} 0.26^{*} 0.12=$ & $47,584^{*} 0.26+112=$ & $\$ 12,621$ \\
$22 * 0.26=6 \mathrm{hrs}$ \\
\hline
\end{tabular}

\section{Results}

\subsection{Investigation of climatic region impact on WT reliability and availability}


Figure 2 shows the average failure rate and downtime values if the breakdown for climatic regions are not considered. Figure 3 shows that annual failure rate per turbine values are at similar range in all climatic regions for subsystems except for hub, rotor blades, generator, gearbox and hydraulic system which happen in Dfc. Rotor blade failures have higher annual failure rates in Dfc than in the other climatic regions whereas hub, generator, gearbox and hydraulic system failures have lower failure rates in Dfc than in the others. Dfc as being a colder climatic region than the rest of the climatic regions in Germany, intuitively, impacted on rotor blade failures however lower hub, generator and gearbox failure rates are counterintuitive. The distortion of the results in gearbox, generator and hub might be attributed to scarcity of data in Dfc climatic region where there are only six wind turbines. For example, six turbines in Dfc region had no more than 0.23 annual failure rate in their gearboxes with two of them had no failure during their survey period, whereas eight in eighteen wind turbines having more than 0.23 annual failure rates in Dfb region six of them being more than 0.5 .

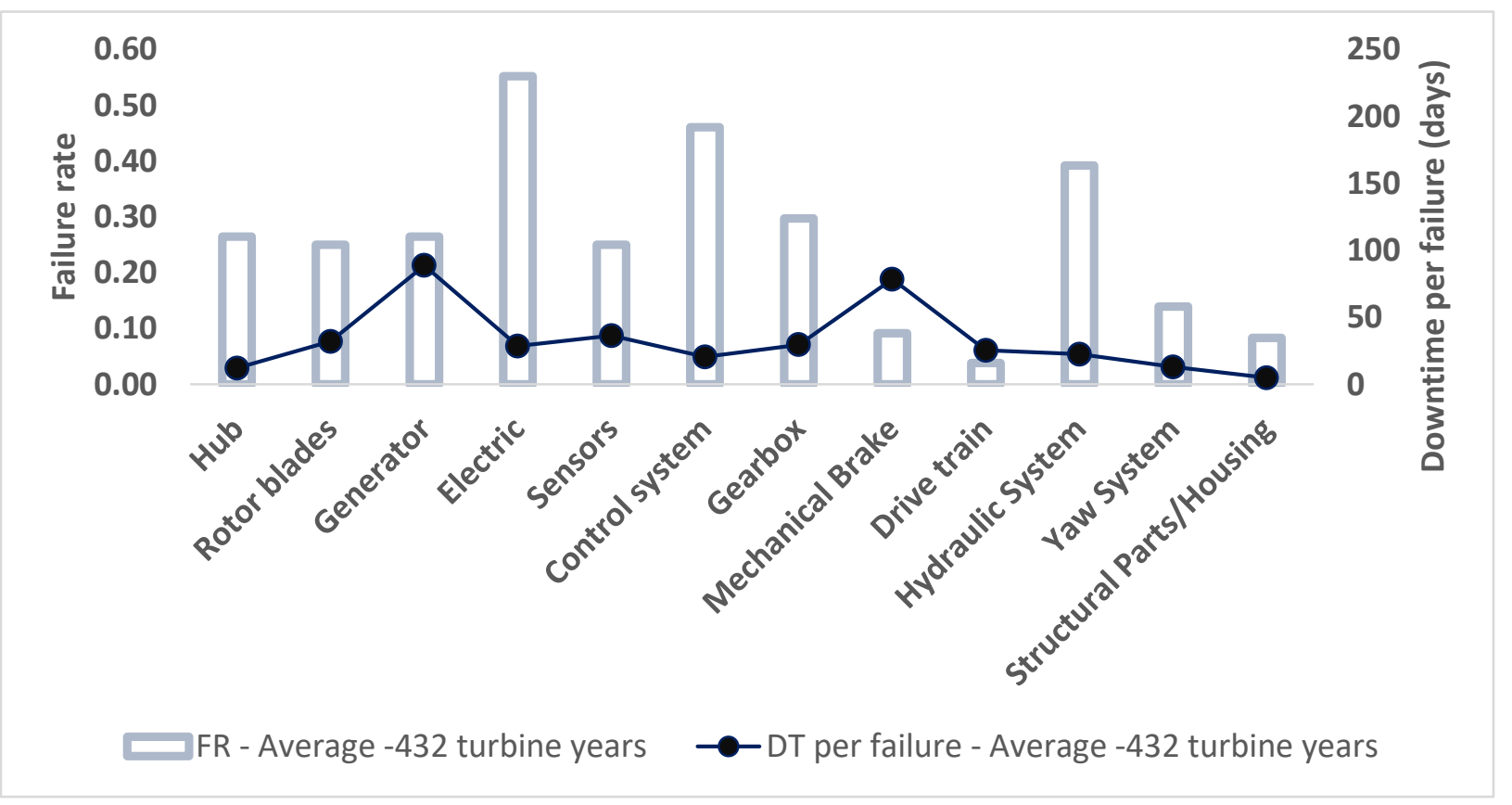

Fig. 2. Averaged failure rate and downtime per failure values for subsystems of one 500-kW geared-drive wind turbine model with $40 \mathrm{~m}$ tower height in different climatic regions 


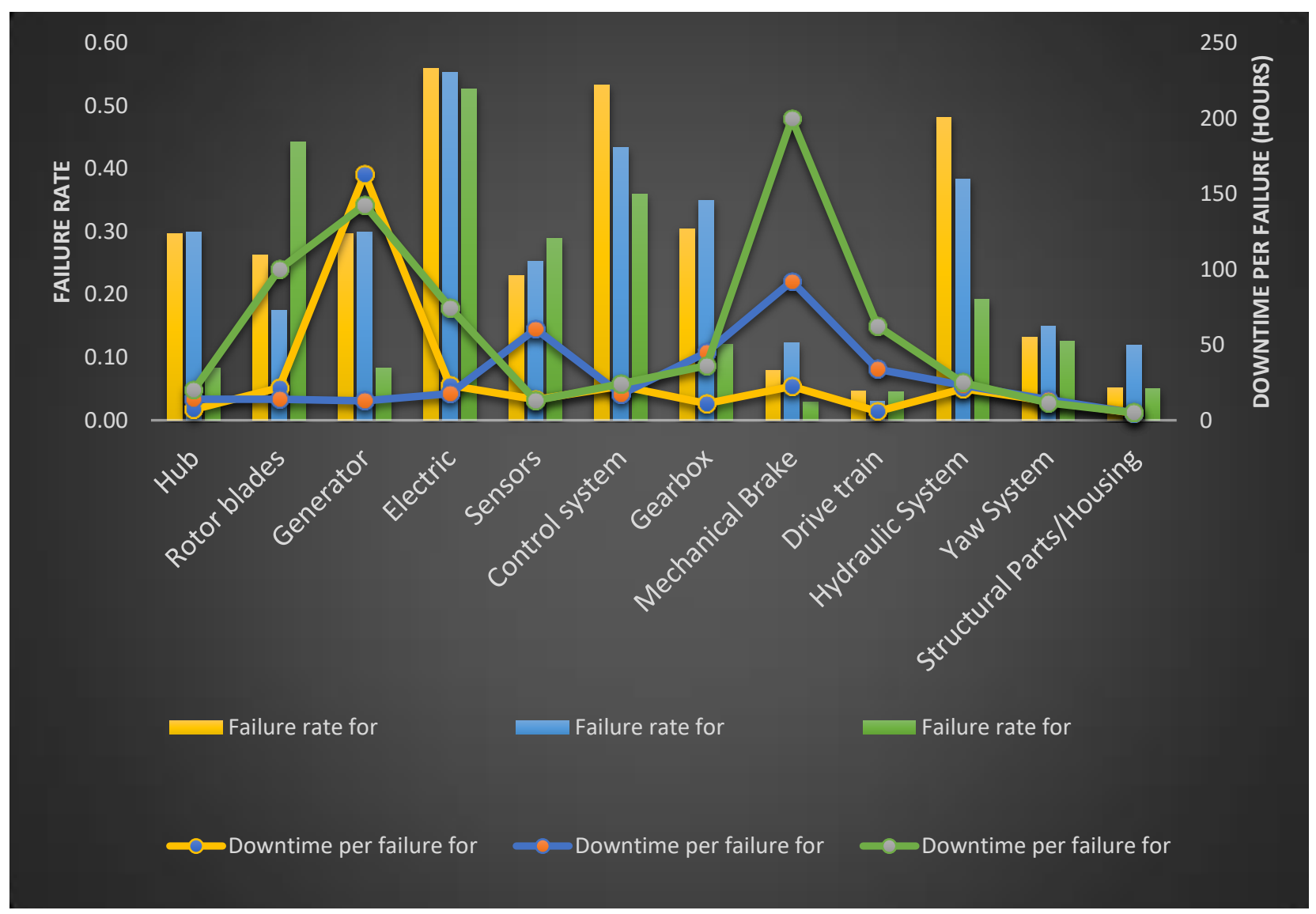

Fig. 3. Annual failure rate and downtime per failure values of subsystems of $500-\mathrm{kW}$ height geared-drive wind turbine model with $40 \mathrm{~m}$ tower in different climatic regions

Figure 3 also demonstrates that the downtime per failure values tend to change depending on the climatic regions. Hub, control system, hydraulic system, yaw system, structures and housing subsystems show comparable results in different climatic regions. Rotor blades and electric system failures show significantly higher downtime per failure values in Dfc, whereas sensor failures have the highest downtime value in Dfb. This might be attributed to severe operational conditions in cold climates. Subsystems in $\mathrm{Cfb}$ region tend to have low downtime per failure - below 24 hours except for generator.

\subsection{FMECA results considering climatic regions}

Table 6 shows the results of downtime and cost criticality values for every subsystem of wind turbines considering their climatic regions. Cost criticality of a subsystem is calculated using equations (1), (2), (3) and (4). Downtime criticality is calculated by multiplying downtime per failure and annual failure rate per subsystem as in Equation (5).

As shown in Table 6 that downtime criticality of subsystems differs depending on the climatic regions. Generator, electric system and control system have higher downtime criticality in $\mathrm{Cfb}$, sensors and gearboxes have higher downtime criticality in Dfb whereas rotor blades and electric 
system have much higher downtime criticality in the climatic region Dfc comparing to the other subsystems.

There is no common cost critical subsystem for wind turbines among different climatic regions as it can be seen from Table 6. Electric system and gearbox are the most critical subsystems for Cfb and Dfb whereas rotor blades are the most cost critical subsystem in climatic region Dfc.

Although structural parts and housing cost criticality shows a significant value in Dfb since the replacement cost imposes a total replacement of tower, foundations and nacelle which is not in the case in the WMEP database, it is ignored for this study.

The main cause for all failures of components of three critical subsystems is component wear or failure, and the associated effect is wind turbine stoppage.

Blade shells are the most affected component by climatic conditions in the rotor blade subsystem as it can be inferred from Figure 4. The climatic region impact is observed in the shares of causes and effects on the components of rotor blades. Loosening of parts are the second major cause after wear of blade components in $\mathrm{Cfb}$ whereas lightning is the biggest major cause for blade shell repairs or replacement in Dfc. Effects of failures in rotor blades are observed to be similar in all climatic regions and being mostly plant stoppage and reduced power.

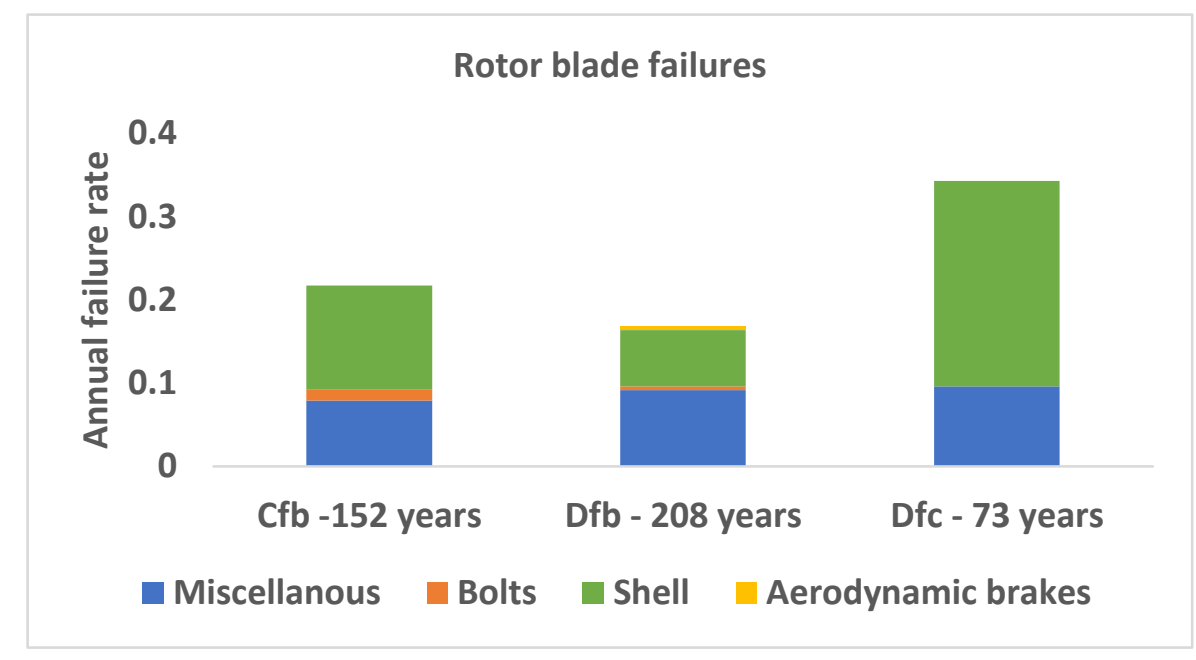




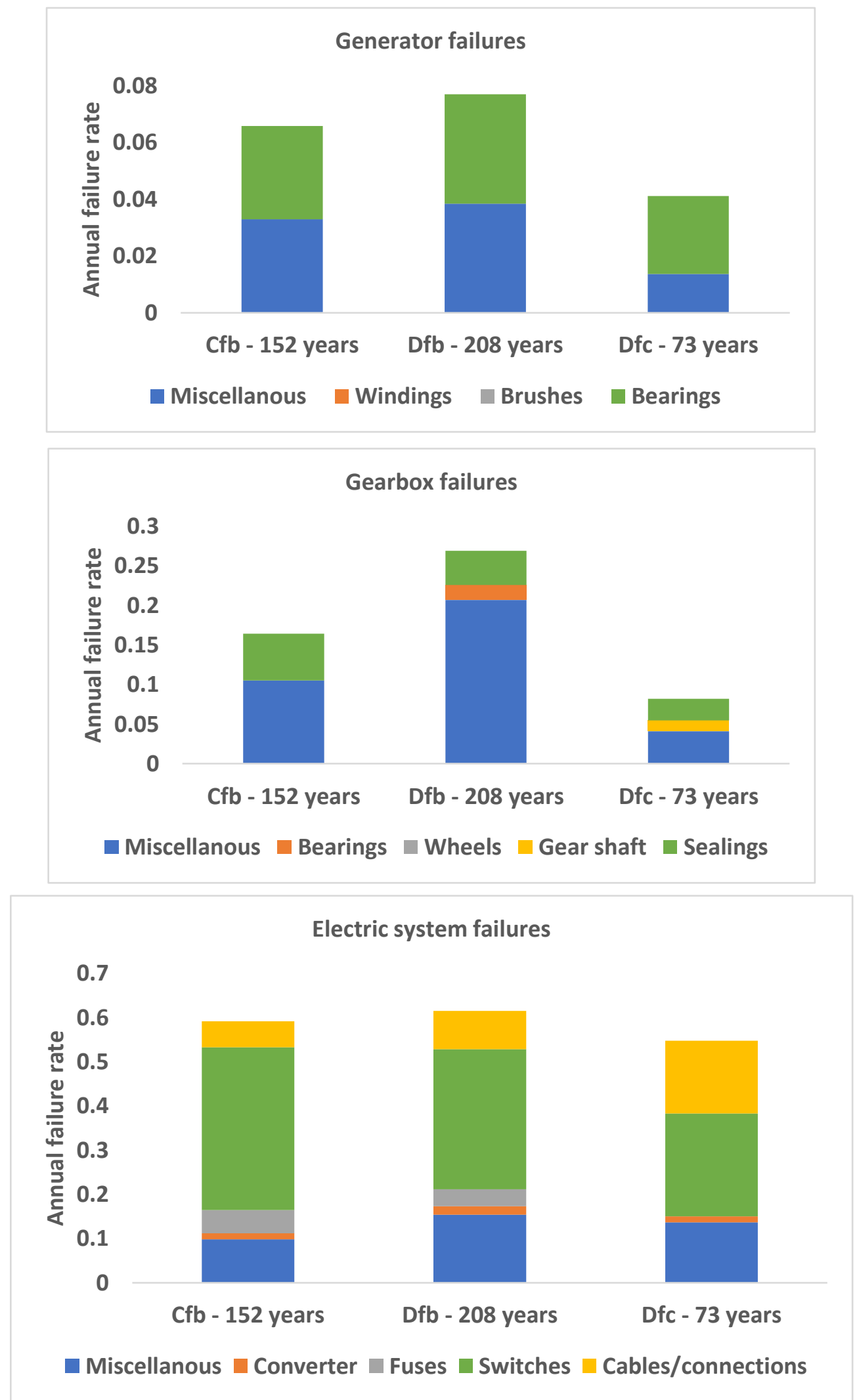

Fig. 4. Distribution of failure rates in components of the most critical subsystems which are mentioned in Table 3 based on climatic regions 
The most critical components in the generator subsystem are bearings as it can be seen in Fig 4 . Wear is the only failure cause in all climatic regions. The significant effect of generator failures is noise, and this is observed in Cfb and Dfb.

Figure 4 shows that miscellaneous gearbox parts are the most affected components in every climatic region followed by sealings in gearbox failures. Wear is the dominant failure cause whereas plant stoppage is the main effect for gearbox in every component. Bearing failures have the noise and vibration effect following plant stoppage predominantly in Dfc climatic region. If it is not the artifact of the data, the reason might be the colder climate with more turbulence that induces more vibration.

The highest failed component in the electric system is switch where in climatic region $\mathrm{Cfb}$ have the highest share with $62 \%$ of total failures as can be seen in Figure 4 . This share is reduced to the minimum $43 \%$ in Dfc where cables and connections are the other highly failed components with $30 \%$ of the failures. Only $10 \%$ of the total failures occurred in cables and connections in Cfb region. The dominant cause is wear in all climatic regions, but the second highest cause vary depending on the region. Lightning and malfunction of control system are the other main failure causes in $\mathrm{Cfb}$ whereas grid failure, which has no contributions in $\mathrm{Cfb}$ and $\mathrm{Dfb}$, significantly contributes to the failures in climatic region Dfc. However, it should be noted that although grid failures are related with regions they are however not related with climatic effects. Plant stoppage is the main cause after failures in all climatic regions only follower is reduced power with slight shares in the failures of switches only in Dfb and Dfc.

Table 6. Downtime and cost criticality comparison based on climatic regions

\begin{tabular}{|c|c|c|c|c|c|c|c|c|c|}
\hline & \multirow{2}{*}{\multicolumn{4}{|c|}{ Downtime Criticality Number (hours) }} & \multirow{2}{*}{\multicolumn{5}{|c|}{ Cost Criticality Number (\$) }} \\
\hline & & & & & & & & & \\
\hline & $\begin{array}{l}\text { Average } \\
\qquad(432 \\
\text { t-years })\end{array}$ & $\begin{array}{l}\text { Cfb (152 } \\
\text { t-years) }\end{array}$ & $\begin{array}{l}\text { Dfb (207 } \\
\mathrm{t} \text {-years) }\end{array}$ & $\begin{array}{l}\text { Dfc } \quad(73 \\
\text { t-years) }\end{array}$ & $\begin{array}{l}\text { Replacement } \\
\text { cost }(\$)[28,29]\end{array}$ & $\begin{array}{l}\text { Average } \\
(432)\end{array}$ & Cfb (152) & $\begin{array}{l}\text { Dfb } \\
(207)\end{array}$ & Dfc (73) \\
\hline Hub & 3 & 2 & 4 & 2 & 38,271 & 10,205 & 11,388 & 11,535 & 3,236 \\
\hline Rotor blades & 8 & 6 & 2 & 44 & 47,584 & 12,052 & 12,621 & 8,365 & 21,958 \\
\hline Generator & 23 & 48 & 4 & 12 & 43,298 & 11,939 & 13,792 & 13,033 & 3,860 \\
\hline Electric & 16 & 13 & 10 & 39 & 59,804 & 33,307 & 33,709 & 33,307 & 32,274 \\
\hline Sensors & 9 & 3 & 15 & 4 & 25,000 & 6,429 & 5,817 & 6,639 & 7,304 \\
\hline Control system & 9 & 12 & 8 & 9 & 10,000 & 4,796 & 5,574 & 4,492 & 3,766 \\
\hline Gearbox & 9 & 3 & 16 & 4 & 51,750 & 15,551 & 15,788 & 18,434 & 6,368 \\
\hline \multicolumn{10}{|l|}{ Mechanical } \\
\hline Brake & 7 & 2 & 11 & 6 & 1,185 & 251 & 130 & 370 & 150 \\
\hline Drive train & 1 & 0 & 1 & 3 & 13,912 & 558 & 645 & 441 & 695 \\
\hline
\end{tabular}




\begin{tabular}{|c|r|r|r|r|r|r|r|r|r|}
\hline $\begin{array}{c}\text { Hydraulic } \\
\text { System }\end{array}$ & 9 & 10 & 9 & 5 & 6,114 & 2,573 & 3,142 & 2,526 & 1,272 \\
\hline Yaw System & 2 & 2 & 2 & 1 & 15,900 & 2,252 & 2,134 & 2,427 & 2,025 \\
\hline $\begin{array}{c}\text { Structural } \\
\text { Parts/Housing }\end{array}$ & 0 & 0 & 1 & 0 & 132,257 & 10,987 & 6,867 & 15,861 & 6,664 \\
\hline
\end{tabular}

\subsection{Direct-drive and geared-drive reliability and availability comparison controlling the climatic region effect}

Figure 5 shows that annual failure rate per subsystem differs between direct-drive and geared-drive wind turbines. Hub, generator, sensors, control system, structural parts and housing subsystems have significantly higher annual failure rates in a $500 \mathrm{~kW}$-direct-drive turbine than a 500 $\mathrm{kW}$-geared-drive wind turbine whereas rotor blades, electric and yaw systems have slightly higher values in the same climatic region. Mechanical brake and drive train have slightly higher annual failure rate in the direct-drive turbine than geared-drive turbine whereas hydraulic system has significantly higher value.

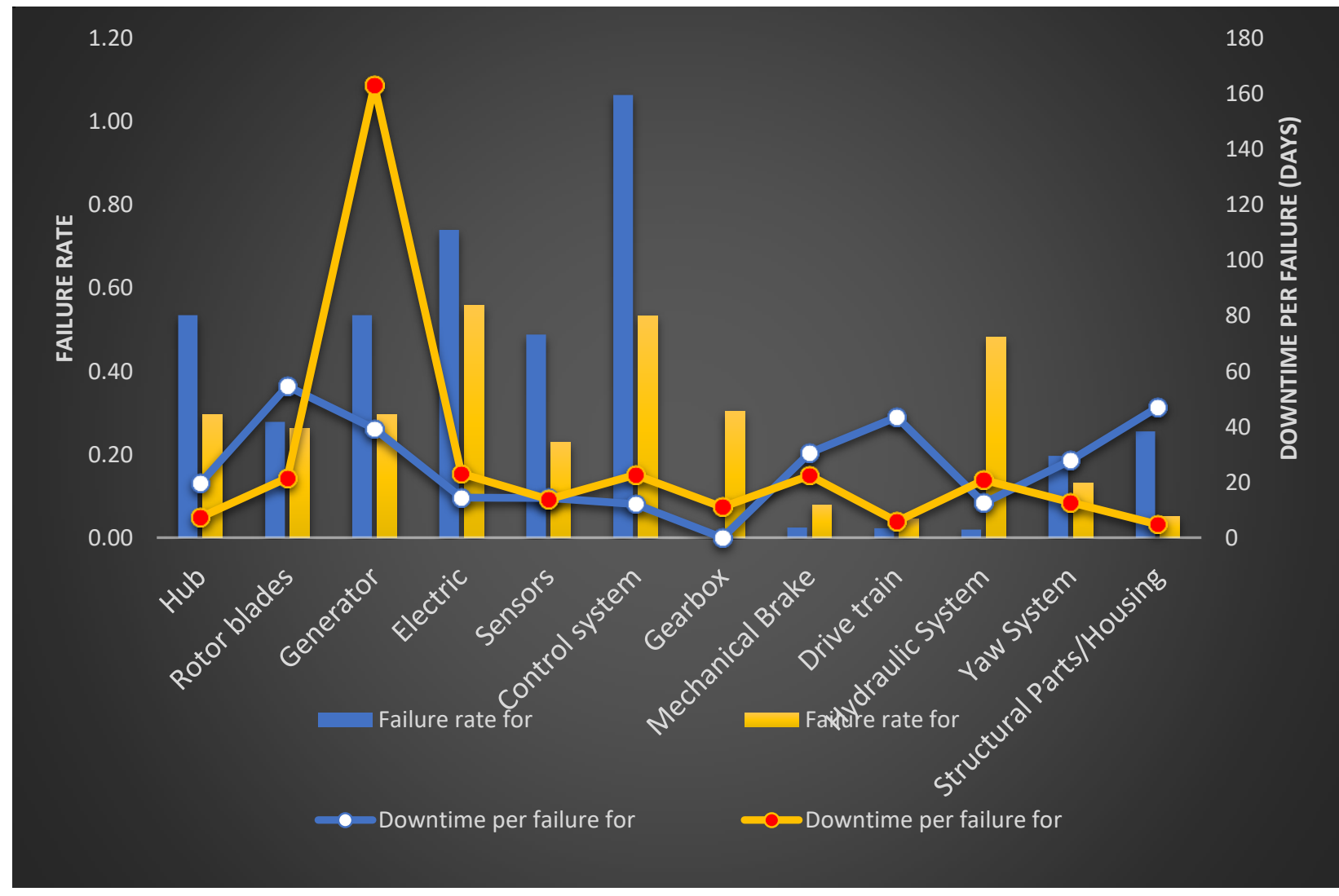

Fig. 5. Annual failure rate per subsystems comparison for direct-drive and geared-drive concept wind turbines 
Figure 5 also demonstrates that downtime per failures vary with the drive design types of wind turbines. Hub, rotor blades, yaw system, structural parts and housing subsystems have significantly higher downtime per failure in $500 \mathrm{~kW}$ direct-drive turbines while generator and hydraulic system have significantly higher downtime per failure in $500 \mathrm{~kW}$ geared-drive wind turbines. Sensors and drive train have slightly higher downtime per failure in direct drive concept whereas electric system, control system and mechanical brake have higher downtime per failure in geared-drive concept.

Furthermore, sensitivity analysis results in Table 7 show that geared-drive capacity change has impacts on downtime per failure values. $200 \mathrm{~kW}$ and $500 \mathrm{~kW}$ turbine models are the same while 300 $\mathrm{kW}$ turbine is another brand. Table 7 shows that the downtime per failure values are significantly higher in $300 \mathrm{~kW}$ turbine for gearbox, rotor blades, drive train and yaw system. Gearbox annual failure rates seem to be increased with capacity increase while downtime per failure has no trend. Control system and electric system are the common highest frequently failed subsystems.

Table 7. Sensitivity analysis for wind turbine capacities

\begin{tabular}{|c|c|c|c|c|c|c|c|c|}
\hline & \multicolumn{2}{|c|}{$\begin{array}{l}\text { Direct-drive-500Kw } \\
\text { (493 turbine years) }\end{array}$} & \multicolumn{2}{|c|}{$\begin{array}{l}\text { Geared-drive-200Kw } \\
\text { (524 turbine years) }\end{array}$} & \multicolumn{2}{|c|}{$\begin{array}{l}\text { Geared-drive-300kW (508 } \\
\text { turbine years) }\end{array}$} & \multicolumn{2}{|c|}{$\begin{array}{l}\text { Geared-drive-500kW } \\
\text { (152 turbine years) }\end{array}$} \\
\hline & $\begin{array}{l}\text { Annual } \\
\text { Failure } \\
\text { Rate }\end{array}$ & $\begin{array}{l}\text { Downtime } \\
\text { Per failure } \\
\text { (hrs) }\end{array}$ & $\begin{array}{l}\text { Annual } \\
\text { Failure } \\
\text { Rate }\end{array}$ & $\begin{array}{l}\text { Downtime } \\
\text { Per failure } \\
\text { (hrs) }\end{array}$ & $\begin{array}{l}\text { Annual } \\
\text { Failure } \\
\text { Rate }\end{array}$ & $\begin{array}{l}\text { Downtime } \\
\text { Per failure } \\
\text { (hrs) }\end{array}$ & $\begin{array}{l}\text { Annual } \\
\text { Failure } \\
\text { Rate }\end{array}$ & $\begin{array}{l}\text { Downtime } \\
\text { Per failure } \\
\text { (hrs) }\end{array}$ \\
\hline Hub & 0.54 & 20 & 0.10 & 10 & 0.15 & 12 & 0.30 & 7 \\
\hline Rotor blades & 0.28 & 55 & 0.09 & 16 & 0.08 & 75 & 0.26 & 22 \\
\hline Generator & 0.54 & 39 & 0.10 & 8 & 0.15 & 90 & 0.30 & 163 \\
\hline Electric & 0.74 & 14 & 0.32 & 19 & 1.15 & 17 & 0.56 & 23 \\
\hline Sensors & 0.49 & 14 & 0.05 & 13 & 0.30 & 15 & 0.23 & 14 \\
\hline $\begin{array}{l}\text { Control } \\
\text { system }\end{array}$ & 1.06 & 12 & 0.36 & 16 & 0.52 & 20 & 0.53 & 23 \\
\hline Gearbox & 0.00 & 0 & 0.09 & 39 & 0.15 & 138 & 0.30 & 11 \\
\hline $\begin{array}{l}\text { Mechanical } \\
\text { Brake }\end{array}$ & 0.02 & 31 & 0.01 & 6 & 0.13 & 23 & 0.08 & 22 \\
\hline Drive train & 0.02 & 43 & 0.03 & 6 & 0.08 & 52 & 0.05 & 6 \\
\hline $\begin{array}{l}\text { Hydraulic } \\
\text { System }\end{array}$ & 0.02 & 13 & 0.11 & 9 & 0.40 & 15 & 0.48 & 21 \\
\hline Yaw System & 0.20 & 28 & 0.09 & 8 & 0.38 & 28 & 0.13 & 13 \\
\hline $\begin{array}{l}\text { Structural } \\
\text { Parts/Housing }\end{array}$ & 0.26 & 47 & 0.04 & 16 & 0.19 & 26 & 0.05 & 5 \\
\hline
\end{tabular}

\subsection{FMECA results on direct-drive and geared-drive wind turbines}

Table 8 shows that the cost criticality of rotor blades, generator, hub, control system and yaw system are significantly higher in direct-drive concepts. Electric system, generator and gearbox are the most cost critical subsystems in the geared-drive wind turbines while generator and electric system have 
the highest cost criticality in direct-drive wind turbines. On the other hand, generator shows the highest downtime criticality for both turbine types.

The dominant failure cause for direct-drive designed wind turbines for rotor blades is wear whereas loosening of parts, high wind and lightning come into play for geared-drive wind turbines. Blade bolts are the most problematic components in the rotor blades subsystems in the direct-drive turbine model whereas the highest failure rate occurred in blade shells in geared-drive wind turbines as it can be seen in Figure 6. The effects of the failures vary depending on the gearing concept of the turbines. The dominant effect is the plant stoppage while noise is the second highest for the direct-drive turbines, whereas reduced power is the main effect for geared-drive wind turbines.

It can be seen from Figure 6 that generator bearings are where the failures mostly occur in geared-drive wind turbines. It is observed that the dominant failure effect is noise in the generator bearings. In direct-drive designed wind turbines miscellaneous parts in the generator subsystem are observed to be as the most affected parts by failures.

Table 8. Downtime and cost criticality comparison based on drive concept of wind turbines in climatic region $\mathrm{Cfb}$

\begin{tabular}{|c|c|c|c|c|c|c|c|c|}
\hline & \multicolumn{2}{|c|}{$\begin{array}{c}\text { Downtime Criticality } \\
\text { Number (hours) }\end{array}$} & \multicolumn{6}{|c|}{ Cost Criticality Number (\$) } \\
\hline & $\begin{array}{c}500 \mathrm{~kW} \\
\text { Direct-dr } \\
\text { ive (493 } \\
\mathrm{t} \text { - years) }\end{array}$ & $\begin{array}{c}500 \mathrm{~kW} \\
\text { geared-dri } \\
\text { ve (152 } \\
\text { t-years) }\end{array}$ & $\begin{array}{c}\text { Direct } \\
\text { drive } \\
\text { turbine } \\
\text { Replaceme } \\
\text { nt cost }(\$) \\
{[25,26]}\end{array}$ & $\begin{array}{l}\text { Cost of lost } \\
\text { energy } \\
\text { production } \\
\text { (\$) }\end{array}$ & $\begin{array}{l}500 \mathrm{~kW} \\
\text { direct- } \\
\text { drive } \\
(493 \mathrm{t}- \\
\text { years) }\end{array}$ & $\begin{array}{c}\text { Geared-drive } \\
\text { turbine } \\
\text { Replacement } \\
\text { cost }(\$) \\
{[25,26]}\end{array}$ & $\begin{array}{c}\text { Cost of } \\
\text { lost } \\
\text { energy } \\
\text { producti } \\
\text { on (\$) }\end{array}$ & $\begin{array}{c}500 \mathrm{~kW} \\
\text { geared-dri } \\
\text { ve (152 } \\
\text { t-years) }\end{array}$ \\
\hline Hub & 11 & 2 & 38,200 & 208 & 20,646 & 38,271 & 43 & 11,388 \\
\hline Rotor blades & 15 & 6 & 51,262 & 301 & 14,569 & 47,584 & 112 & 12,621 \\
\hline Generator & 21 & 48 & 120,463 & 416 & 64,865 & 43,298 & 957 & 13,792 \\
\hline Electric & 11 & 13 & 59,804 & 211 & 44,461 & 59,804 & 256 & 33,709 \\
\hline Sensors & 7 & 3 & 25,000 & 139 & 12,343 & 25,000 & 63 & 5,817 \\
\hline Control system & 13 & 12 & 10,000 & 256 & 10,900 & 10,000 & 240 & 5,574 \\
\hline Gearbox & 0 & 3 & 13,097 & 0 & 0 & 51,750 & 67 & 15,788 \\
\hline $\begin{array}{c}\text { Mechanical } \\
\text { Brake } \\
\end{array}$ & 1 & 2 & 1,185 & 15 & 44 & 1,185 & 35 & 130 \\
\hline Drive train & 1 & 0 & 13,997 & 20 & 338 & 13,912 & 5 & 645 \\
\hline $\begin{array}{l}\text { Hydraulic } \\
\text { System }\end{array}$ & 0 & 10 & 6,114 & 5 & 127 & 6,114 & 199 & 3,142 \\
\hline Yaw System & 5 & 2 & 16,260 & 109 & 3,305 & 15,900 & 33 & 2,134 \\
\hline
\end{tabular}




\begin{tabular}{|c|r|r|r|r|r|r|r|}
\hline $\begin{array}{c}\text { Structural } \\
\text { Parts/Housing }\end{array}$ & 12 & 0 & 228,095 & 238 & 58,511 & 132,257 & 5 \\
\hline
\end{tabular}

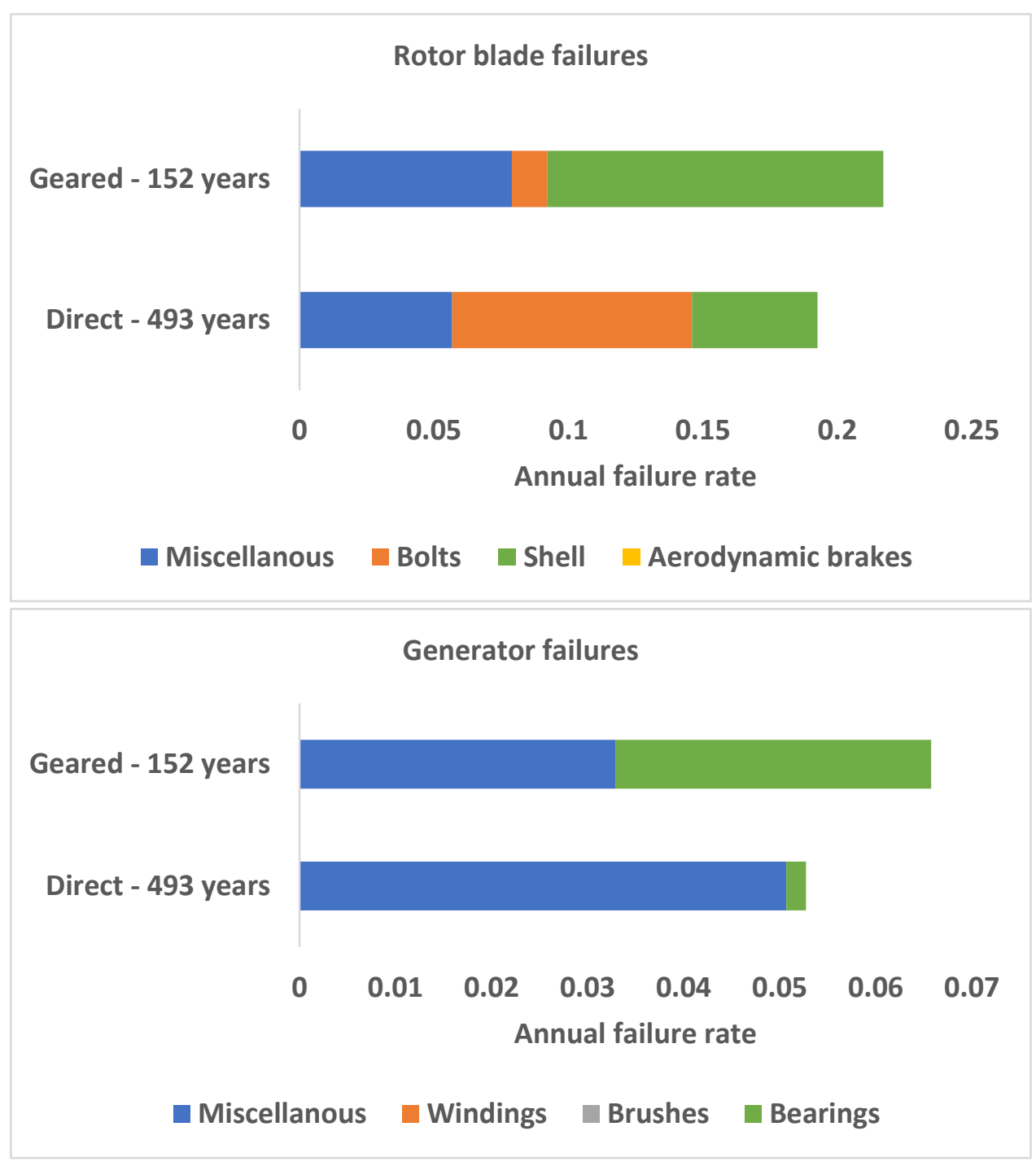




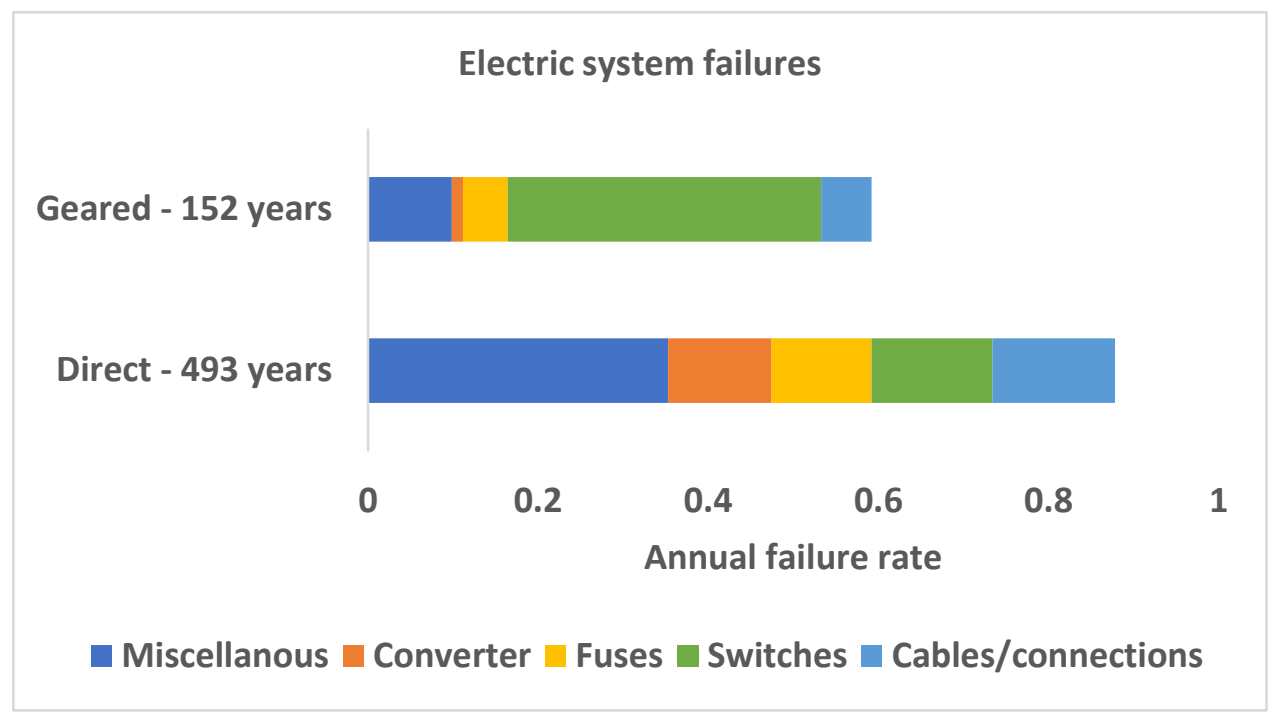

Fig 6. Distribution of failure rates in the components of the common critical subsystems which are mentioned in Table 3 in geared and direct-drive wind turbines

Converter, fuses and switches fail mainly because of the wear or component failure followed by the malfunction of control system in direct-drive design wind turbines as it is seen in Figure 6. 62\% of the failures occur in switches in a geared-drive wind turbine, while this is reduced to $16 \%$ for switches in direct-drive turbine. It seems that lightning can be accounted for being a significant failure cause for electric system for geared-drive wind turbines but not for direct-drive turbines. All these differences might be attributed to the quality and durability of materials used in these turbines.

\section{Discussion}

Comparing different wind turbines, the main differences are in generator types of two wind turbine types and namely those having gearbox and those with direct-drive. The rest of the subsystems have same functionality while they might be made of different materials with varying quality. The considered direct-drive wind turbine in this study has a synchronous type generator with 38 rotations per minute $(\mathrm{rpm})$ generating $440 \mathrm{~V}$ output whereas the geared-drive wind turbine has an asynchronous generator with $1522 \mathrm{rpm}$ and $690 \mathrm{~V}$ output. The total weight of the direct-drive wind turbine is much higher than the geared-drive wind turbine generator, $125 \mathrm{t}$ and $85 \mathrm{t}$, respectively. Furthermore, electric system, control system, yaw system and hydraulic system might differ in two turbine designs, as well as in general between any turbine models.

Shafiee and Dinmohammadi [10] found the highest criticalities in rotor blades, gearbox and transformer with 5,326 €, 4,542 € and 1,371 € cost criticality numbers for onshore wind turbines, respectively. For offshore wind turbines, cost criticality of rotor blades increased dramatically to $16,831 €$, as it confirms the results from our study that criticality of subsystems can change abruptly in a harsh environment [10]. Kahrobaee and Asgarpoor [16] used 3 MW direct drive wind turbine as a case study. Generator is determined as the highest critical subsystem with $\$ 14,110$ followed by electrical system with $\$ 3,274$ and rotor blades $\$ 2,541$ This represents the similar criticality order for 
subsystems with our study for a direct drive turbine, but the scale of cost criticality values is different than our study. This difference may be attributed to the differences of replacement cost assumptions of two studies. Tazi et al [20] found gearbox, rotor blades and yaw system with the highest cost criticality numbers of $49,356 €, 45,367 €$ and $30,811 €$, respectively, ignoring tower, for 2 and $3 \mathrm{MW}$ wind turbines. We found that electric system, generator and gearbox as the most critical subsystems in a geared-wind turbine with $\$ 33,709, \$ 13,792$ and $\$ 12,621$ cost criticality, respectively. In our study, electric system seems to be an addition into the highest cost critical subsystems mainly because of having higher material and installation cost share in a small-scale turbine like $500 \mathrm{~kW}$ than a bigger turbine such as 2-3 MW turbine. The highest cost critical subsystems agree between our study and studies in the literature which used same approach for cost criticality evaluations [10, $16,20]$. Slight differences are observed as it is supposed to be because of the differences of reference wind turbine sizes, locations and types.

\section{Conclusions}

This paper aims to assess the impacts of weather and turbine type by applying Failure Modes Effects and Criticality Analysis (FMECA) on a large number of wind turbines. The reliability and availability behavior of the wind turbine design in different climatic regions of Germany are investigated and differences determined. Also, FMECA is applied to compare criticalities of geared-drive and direct-drive wind turbine subsystems controlling climatic conditions as a first time in the literature. Our findings can be summarized as follows:

- Considering climatic regions in FMECA revealed differences in failure rate and downtime behaviors of subsystems in the wind turbines that were not reported in previous studies.

- Climatic regions have an impact on the critical subsystems and failure causes in wind turbines. This implies that the wind turbine operations and maintenance strategies for subsystems should be arranged taking local climatic conditions of the turbines into account. For example, rotor blade downtimes and failure rates are impacted by colder climates where longer downtime and higher failure rates are observed. Also, lightning became an important failure cause in cold climatic regions for rotor blade failures.

- In most of the subsystems direct-drive wind turbines seemed to have a higher failure rate than geared-drive wind turbine in the same climatic region. Direct-drive technology would be thought to be an ideal design for offshore applications because of its less complexity, however this study shows opposite. To come to a solid conclusion though, this comparison should be done with and extensive data with many different make and models of wind turbines in the future.

The main outcome from the current study is that downtime and cost criticalities of subsystems of wind turbines depend on the locations and types of wind turbines. Wind farm operators should consider location and type of turbine factors for their O\&M budget allocation and arrange the maintenance strategies correspondingly. Furthermore, the insurance companies can benefit utilizing 
climatic regions such as Koppen-Geiger to evaluate and classify the risk of turbine subsystems. Although this study is limited to 1989-2008 data, the proposed methodology and lessons from this study are expected to be globally applicable. Further research would include relatively newer wind turbines which spread on a geographic area with many different climatic regions along with failure data to better improve our understanding on distinguishing climatic regions effect on FMECA for wind turbines.

\section{References}

1- GWEC (2017). Global Wind Report 2016 - Annual market update. [online] Gwec.net. Available at: http://gwec.net/publications/global-wind-report-2/global-wind-report-2016// [Accessed 3 March 2018].

2- IEC 60050-192:2018. International Electrotechnical Vocabulary - Part 192: Reliability

3- IEC 60050-192:2018. International Electrotechnical Vocabulary - Part 192: Availability

4- Teng, Sheng-Hsien, and Shin-Yann Ho. "Failure Mode and Effects Analysis An Integrated Approach for Product Design and Process Control." The International Journal of Quality \& Reliability Management; Bradford 13, no. 5 (1996): 8-26.

5- Andrawus, Jesse A., John Watson, Mohammed Kishk, and Allan Adam. "The Selection of a Suitable Maintenance Strategy for Wind Turbines." Wind Engineering 30, no. 6 (December 1, 2006): 471-86. https://doi.org/10.1260/030952406779994141.

6- Arabian-Hoseynabadi, H., H. Oraee, and P. J. Tavner. "Failure Modes and Effects Analysis (FMEA) for Wind Turbines." International Journal of Electrical Power \& Energy Systems 32, no. 7 (September 1, 2010): 817-24.

7- Das, M. K., S. C. Panja, S. Chowdhury, S. P. Chowdhury, and A. I. Elombo. “Expert-Based FMEA of Wind Turbine System." In 2011 IEEE International Conference on Industrial Engineering and Engineering Management, 1582-85, 2011. https://doi.org/10.1109/IEEM.2011.6118183.

8- Fischer, K., F. Besnard, and L. Bertling. "Reliability-Centered Maintenance for Wind Turbines Based on Statistical Analysis and Practical Experience." IEEE Transactions on Energy Conversion 27, no. 1 (March 2012): 184-95. https://doi.org/10.1109/TEC.2011.2176129.

9- Dinmohammadi, F., \& Shafiee, M. (2013). A Fuzzy-FMEA Risk Assessment Approach for Offshore Wind Turbines.

10- Shafiee, Mahmood, and Fateme Dinmohammadi. "An FMEA-Based Risk Assessment Approach for Wind Turbine Systems: A Comparative Study of Onshore and Offshore." Energies 7, no. 2 (February 10, 2014): 619-42. https://doi.org/10.3390/en7020619.

11- Karyotakis, A. On the Optimization of Operation and Maintenance Strategies for Offshore Wind Farms. Ph.D. Thesis, Department of Mechanical Engineering, University College London, London, UK, 2011.

12- Besnard, F. On Maintenance Optimization for Offshore Wind Farms. Ph.D. Thesis, Department of Energy and Environment, Chalmers University of Technology, Gothenburg, Sweden, 2013. 
13- Shafiee, M.; Patriksson, M.; Strömberg, A.-B.; Bertling, L. A Redundancy Optimization Model Applied to Offshore Wind Turbine Power Converters. In Proceedings of the IEEE PowerTech Conference, Grenoble, France, 16-20 June 2013; doi:10.1109/PTC.2013.6652427

14- Van Bussel, G.; Zaaijer, M. Estimation of Turbine Reliability Figures within the DOWEC Project; DOWEC Report; Energy Research Centre of the Netherlands (ECN): Petten, The Netherlands, 2003; Available online: https://www.ecn.nl/fileadmin/ecn/units/wind/docs/dowec/10048_004.pdf (accessed on 7 June 2018).

15- Sinha, Y., and J. A. Steel. "A Progressive Study into Offshore Wind Farm Maintenance Optimisation Using Risk Based Failure Analysis." Renewable and Sustainable Energy Reviews 42 (February 1, 2015): 735-42. https://doi.org/10.1016/j.rser.2014.10.087.

16- Kahrobaee, S., and S. Asgarpoor. “Risk-Based Failure Mode and Effect Analysis for Wind Turbines (RB-FMEA)." In 2011 North American Power Symposium, 1-7, 2011. https://doi.org/10.1109/NAPS.2011.6025116.

17- Sheng, Shuangwen, and Paul Veers. Wind Turbine Drivetrain Condition Monitoring - An Overview, 2011.https://doi.org/10.1016/j.ijepes.2010.01.019.

18- Tavner, P.J., A Higgins, H Arabian, Hui Long, and Yanhui Feng. Using an FMEA Method to Compare Prospective Wind Turbine Design Reliabilities. Vol. 4, 2010.

19- Bharatbhai, M.G. Failure mode and effect analysis of repower $5 \mathrm{MW}$ wind turbine. Int. J. Adv. Res. Eng. Sci. Technol. 2015, 2, 2393-9877.

20- Tazi, Nacef, Eric Châtelet, and Youcef Bouzidi. “Using a Hybrid Cost-FMEA Analysis for Wind Turbine Reliability Analysis." Energies 10, no. 3 (February 27, 2017): 276. https://doi.org/10.3390/en10030276

21- Faulstich, S.; Lyding, P.; Hahn, B. Electrical components of wind turbines, a substantial risk for the availability. In Proceedings of the European Wind Energy Conference and Exhibition (EWEC), Warsaw, Poland, 20-23 April 2010

22- Vindkraft, D. Driftuppföljning Vindkraft (Wind Turbine Operation). June 2016. Available online: http://vindstat.com/rapporter-2/ (accessed on 7 June 2018).

23- Stenberg, A. Analys av Vindkraftsstatistik i Finland (Wind Turbine Analysis in Finland). Master's Thesis, VTT, Stockholm, Sweden, 2010. Available online: http://www.vtt.fi/files/projects/windenergystatistics/diplomarbete.pdf (accessed on 6 June 2018).

24- Herman, K.; Walker, R.; Winikson, M. Availability Trends Observed at Operational Wind Farms. In Proceedings of the European Wind Energy Conference \& Exhibition (EWEC) 2008, Brussels, Belgium, 31 March-3 April 2008.

25- Peel, Murray, Brian Finlayson, and Thomas Mcmahon. "Updated World Map of the Koppen-Geiger Climate Classification." Hydrology and Earth System Sciences Discussions 4 (2007).

26- Andrawus, J. Maintenance Optimization for Wind Turbines. Ph.D. Thesis, School of Engineering, Robert Gordon University, Aberdeen, UK, 2008. 
27- Amirat, Y., M. E. H. Benbouzid, E. Al-Ahmar, B. Bensaker, and S. Turri. “A Brief Status on Condition Monitoring and Fault Diagnosis in Wind Energy Conversion Systems." Renewable and Sustainable Energy Reviews 13, no. 9 (December 1, 2009): 2629-36.

https://doi.org/10.1016/j.rser.2009.06.031.

28- L. Fingersh, M. Hand, A. Laxson. Wind turbine design cost and scaling model. National Renewable Energy Laboratory, Golden, CO (2006).

29- R. Poore, C. Watford. Development of an operations and maintenance cost model to identify cost of energy savings for low wind speed turbines. Technical Report NREL/SR-500-40581. National Renewable Energy Laboratory (NREL), Albuquerque, New Mexico, USA (2008).

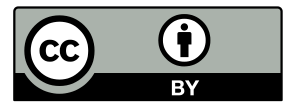

(C) 2018 by the authors. Submitted for possible open access publication under the terms and conditions of the Creative Commons Attribution (CC BY) license (http://creativecommons.org/licenses/by/4.0/). 